\title{
PROBLEMS AND PROSPECTS OF COOPERATION OF THE BORDER REGIONS OF UKRAINE, ROMANIA, MOLDOVA AND SLOVAKIA
}

\author{
Liudmyla Chobal' ${ }^{1}$, Mariya Lalakulych²
}

\begin{abstract}
The purpose of the paper is to outline the legal framework for the development of UkrainianMoldovan, Ukrainian-Slovak and Ukrainian-Romanian transborder regions (TBR), in particular in the context of intergovernmental agreements, national legislation on issues of cross-border cooperation, agreements between local authorities and regional cross-border regulatory support. The international cooperation of the Western region of Ukraine from the side of the authorities is focused mainly on the western vector, on relations with Poland. In our view, such regional policy leads to increasing regional differences in the socio-economic development of the Lviv and Ivano-Frankivsk regions, in particular their northern and southern parts. The intensification of the cross-border cooperation with Romania will create promising conditions for the transformation of a number of southern regions of the Carpathian region into a zone of accelerated economic development. This can be done through the development of transport, tourism and recreation, finance, logistics infrastructure, which will increase the attractiveness of the territories. And for this it is necessary to create an economic climate in the southern districts of the region, which would help attract foreign investment, especially Romanian, possibly by creating special or free economic zones there. The region has significant untapped potential of the Ukrainian-Romanian interaction that can be harnessed. The Ukrainian-Slovak and Ukrainian-Moldovan cooperation should also be strengthened in the region, the latter especially for the purpose of the European integration of Ukraine and Moldova. To this end, the article outlines the regulatory framework for the development of the Ukrainian-Moldovan, Ukrainian-Slovak and Ukrainian-Romanian transborder regions, in particular in the context of interstate agreements, national legislation on cross-border cooperation, agreements between local authorities and regional transborder security. The article describes the current state of subregional cooperation within the transborder regions, identifies the problematic issues of such cooperation, as well as reveals its content through the lens of the Euroregional cooperation. Methodogy. The dialectical method of scientific knowledge, method of analysis and synthesis, comparative method, method of data generalization are used in the paper. Results of the research. A description of the current state of subregional cooperation within the framework of the TBR is given, the problems of such cooperation are revealed, and its content is revealed through the prism of Euroregional cooperation. The key international projects of the development of the transborder regions were identified and their content and significance were analyzed for the improvement of the ecological safety of TBR, their entrepreneurship development, activation of innovation activities, the development of the border infrastructure, deepening of cultural interaction, improvement of urban development, revival of trade and investment activity in the above-mentioned transborder regions. The perspective directions of development of these TBRs are determined.
\end{abstract}

Key words: transborder region, growth potential, strategy, energy security, eurointegration, tourism, clusters, international cooperation.

JEL Classification: F15, 019

\footnotetext{
Corresponding author:

${ }^{1}$ Uzhhorod Trade and Economic Institute of Kyiv National University of Trade and Economics, Ukraine.

E-mail: cobalyudmila@gmail.com

ORCID: https://orcid.org/0000-0002-9838-4051

${ }^{2}$ Uzhgorod Trade and Economic Institute of Kyiv National University of Trade and Economics, Ukraine.

E-mail: lalakylich.mariya1969@gmail.com

ORCID: https://orcid.org/0000-0003-1027-9458
} 


\section{Introduction}

Formulation of the problem. Complete modernization of the national economy, its effective integration into the world economy, European integration processes are inconceivable without the activation of the crossborder cooperation, especially with the EU. And in light of this cooperation border areas which cover this interaction should be in the center of the state regional policy in the Western region of Ukraine. However, in practice, such border areas as Carpathians (for example the Verkhovyna district) paid little attention. As a result, these areas are actually economically backward at that time, and cross-border cooperation was almost absent until recently. The same applies to the border regions of Ukraine adjoining to Slovakia and Moldova. However, some positive steps towards progress on them are still and we want to stay on this in the study. The task was given to identify key international projects for the development of the Ukrainian-Slovak, UkrainianRomanian and Ukrainian-Moldovan transborder regions and to analyze the content and importance of projects for improving the environmental security of the TBRs, development of entrepreneurship, enhancement of innovative activity, development of border infrastructure, deepening urban development, revitalization of trade and investment activity in the above-mentioned transborder regions, identify promising directions of development of these transborder regions.

Analysis of recentresearch and publications. Considerable attention of researchers is devoted to the problems of cross-border cooperation and interaction of entities in transboundary space, development of border areas in conditions of intensification of European integration processes, cooperation between border communities. In particular, such scientists as S. Hacman (Hacman, 2004), O. Havashi (Havashi, 2013), Y. Kish (Kish, 2004), V. Kotsur (Kotsur, 2013), V. Kryvous (Kryvous, 2006), N. Kulya (Kulia, n.d.), O. Kyfyak (Kyfiak, 2007), A. Milashovska (Milashovska, 2008), S. Mitryayeva (Mitriaieva, 2005) and others worked over this issue. However, insufficient attention is devoted for the current state of border areas and search of ways for their development. In this regard, our research is focused on studying the development characteristics of such border areas as the Ivano-Frankivsk, Vinnytsia, Odesa and Transcarpathian regions in terms of border cooperation with the EU regions.

Methodology. The dialectical method of scientific knowledge, method of analysis and synthesis, comparative method, method of data generalization are used in the paper.

The purpose of the article is to identify problems and outline the perspective directions of activating the interaction of the border regions of Ukraine, Moldova, Romania and Slovakia.

\section{Problems and prospects of cooperation of the border regions}

The structure of the Ukrainian-Slovak transborder region includes three administrative units: the Transcarpathian region from the Ukrainian side, Presov and Kosice regions of Slovakia from the Slovak side. The districts Sobrance, Mihajlivka and of Kosice region and district Snina of Presov region in Slovakia border directly with Ukraine, and districts Velykyi Bereznyi, Perechyn and Uzhhorod of Transcarpathian region border with Slovakia. Ukrainian-Slovak cross-border region covers a total area of $28,504 \mathrm{~km}^{2}$. Among all its neighboring countries, Ukraine has the shortest state border with Slovakia, which length reaches $97.85 \mathrm{~km}$. There are located 6 crossing points and control points on the border, including three rail (Uzhhorod, Chop (Strazh), Pavlove), two cars (Uzhhorod, Malyi Bereznyi), one bike-pedestrian (Mali Selmentsi) borders. The average distance between checkpoints is $19.57 \mathrm{~km}$ that corresponds to EU standards.

Increased interaction between two parts of the Ukrainian-Slovak transborder region takes place on the large enough basis of the bilateral legal framework, including 50 interregional and 30 strategically important for the development of TBR agreements between subjects. The most important among them are certainly Agreement on small border traffic, Agreement on promotion and mutual protection of investments, as well as Memorandum of Understanding between Ukrtransgaz JSC (Ukraine) and Eustream a.s. (PLC) (the Slovak Republic) on the reverse gas supplies to Ukraine through Slovakia, transborder region in hub of gas and energy or its important element (underground gas storage facilities in Western Ukraine) for enhance of energy security of Ukraine, following the example of existing Iranian, British and Kazakh models.

The Ukrainian-Slovak transborder region is involved in the functioning of the Carpathian Euroregion, in frame of which the projects are aimed at the development of municipal and green tourism, revival and preservation of cultural heritage, forming the base of investment ideas and fundraising, development of infrastructure and utilities sector, strengthening of environmental safety and setting up of information exchange. However, we believe that Euroregional cooperation ("Lemkivshchyna") should also be implemented within the same Ukrainian-Slovak TBR and based on energy and tourism components. This would allow to take into account the specifics of Ukrainian-Slovak TBR more fully and to build its development strategy on that basis.

Despite its small size and relatively small population, Slovakia has a number of competitive advantages, including: membership in the European Union; entry into the Schengen area and the euro area; developed automotive industry; developed tourism, agricultural sector and pharmaceutical industry; extensive 
experience in the establishment and functioning of industrial parks; successful experience of the Euroregional cooperation. This makes it one from priority partners for Ukraine in the field of cross-border cooperation and determines the appropriate specificity of the Ukrainian-Slovak transborder region. Despite the relatively short length of the Ukrainian-Slovak border $(99 \mathrm{~km})$, this region has significant potential for social and economic growth, which so far had realized and come mainly to administrative and cultural-ethnic issues of establishing of mutual cooperation.

Important steps of establishing inter-regional cooperation within the transborder region became ratification of the Agreement on local border traffic between Ukraine and the Slovak Republic (Decree of the President of Ukraine No. 697/2008 dated August 6 , 2008) (the Verkhovna Rada of Ukraine, 2008), the Agreement between Ukraine and the Slovak Republic on promotion and mutual protection of investments (signed on February 26, 2007) and signing of the Memorandum of mutual understanding between Ukrtransgaz JSC (Ukraine) and Eustream a.s. (PLC) (the Slovak Republic) on the reverse gas supplies to Ukraine through Slovakia and other contractual documents in political, consular-visa, trade-economic, energetic, transport fields, etc. These steps contributed to the growth of investment attractiveness of the Ukrainian-Slovak TBR, its establishment as a strategic area of the energy security of Ukraine strengthening and its organizational design. However, it should also be noted that despite all the positive effects of the signing of the Agreement on small border traffic, its performance showed a large gap in social and economic living standards of transborder region. In particular, the Slovak shopping tours in Transcarpathia is very beneficial for local businessmen, but prices for local goods and services are increasing for the population, which make them less able to purchasing. In addition, act of this Agreement applies to the 30-kilometer border zone, not on the 50-kilometer, as provided in similar agreements with Poland and Hungary. This means less coverage range of residents for the Ukrainian-Slovak TBR that can enjoy the benefits of the agreement. Thus, the Ukrainian side of the state border agreement covers 280 cities and villages. An additional obstacle to the implementation of the agreement is bureaucracy from the Slovak side (Bureau of Border and Foreign Police in the Ministry of Internal Affairs of the Slovak Republic), which requires an invitation, a large amount of information, evidence, justification, arguments and questionnaires or 3-year permanent residence in the border zone, a mandatory fee in 20 euro and compulsory indication and proof of travel reasons. As we know, the practice of introducing local border traffic is the norm of the EU, which aims to encourage ethno-related, cultural and historical ties between the citizens of neighboring countries. Of course, the current situation on the
Slovak-Ukrainian state border is not conducive to the full and in-depth development of the Ukrainian-Slovak transborder region.

We think that the establishment of the cross-border cooperation between Ukraine and the Slovak Republic should be based and united around the idea of the European integration, because from all the western countries neighboring with Ukraine Slovakia proved to be most successful in this process. In this regard, more attention needs expanding of activities and increasing of the transfer of functions of the Center for Experience Transfer in Integration and Reforms (CETIR), which has been operated in the Foreign Ministry of Slovakia since 2010 and is intended to improve the qualifications of representatives of Ukraine in the ministries and departments of the Slovak Republic.

In the cut of the economic issues bloc of the UkrainianSlovak transborder region development the definitely helpful priority in establishing of closer cooperation is spreading of the Slovak experience in attracting of investments for the Ukrainian part of TBR. Thus, in its frames a list of tax exemptions and preferences is defined for investors that differentiated depending on the amount of investment, but also expected the practice of mandatory compensation of costs on creating of jobs and partial covering the capital costs of transborder region should be supported by a set of objective factors, among which the political and ethnocultural component has important value, taking into consideration the European integration aspirations of Ukraine, centuries-old ethnic and historical proximity (the historical region of Lemkivshchyna) and today presence of quite numerous Ukrainian minority in Slovakia and the Slovak minority in Ukraine.

In recent years one of the most pressing issues of TBR development was the issue of strengthening of state border security and border infrastructure development. A key threat on the Ukrainian-Slovak state border is the proactive acts of criminal gangs that engaged by trafficking of persons, moving of tobacco products, drugs, stolen cars, goods and cargoes and so on. Affair of the so-called "Underground tunnel junction" (UNIAN, 2012) through the Ukrainian-Slovak border acquired wide publicity in 2012

Despite some difficulties, the Ukrainian-Slovak transborder region has a very strong potential for interregional cooperation. In particular, currently 50 agreements on cooperation at various levels of regions, districts and municipalities are concluded. Also about 30 documents on cooperation between institutions are signed, the implementation of which provides contacts at the micro level: between certain structures, enterprises, universities, schools, research institutions, cultural institutions, libraries, etc., that allow regular conduction the joint activities, scientific conferences, round tables, workshops, forums, colloquiums, etc. 
The Agreement on interregional cooperation between Ivano-Frankivsk Regional State Administration and the Council of the Maramures county was signed on March 29,2008 . The document dealt with the setting up the regional cooperation in trade-economic, scientifictechnical and cultural spheres. Regarding implemented measures by the Agreement, joint action plans were developed and implemented; promising direction with the Romanian experience in the European integration and the use of EU funds is introduced. Also the visit of the official delegation of the Ivano-Frankivsk region to the Maramures county was agreed, led by the head of the regional state administration.

In addition, was realized Romania-Ukraine Neighbourhood Programme "Creating of cross-border network for development and promotion of tourism and investment opportunities in the Ivano-Frankivsk region of Ukraine and the Maramures county of Romania" (Odessa Region State Administration, 2016). This is, in essence, the basic meaningful project of the interregional cooperation. Its general goal is the creation of conditions and framework for development of the cross-border tourism in two border regions. The implementation of project is aimed at: 1) launching of initiatives for cooperation with the Romanian agencies and exchange of experience through the development of institutions and institutional framework for the crossborder tourism; 2) improving the quality and quantity of services in the regions, which can take local and international visitors; 3 ) joint creating of the system of tourism promoting; 4) searching and exploring of the possibilities for simplification of the passage of the Ukrainian-Romanian border for pedestrians and cyclists. The anticipated results of the project execution: initiatives for cooperation in experience exchange with the Romanian agencies through the development of institutions and institutional framework for the crossborder tourism under the leadership of the UkraineRomanian Resource Center for Tourism and Business (Ivano-Frankivsk); improving the quality and quantity of services in the regions, which can receive local and international visitors; creation of a joint UkrainianRomanian tourism promotion system that includes conducting of marketing research on the cross-border tourism, organization of study tours, dissemination of information materials and joint participation in national tourism events; setting to work dialogue with the border authorities of both countries at the opening of the border for pedestrians and cyclists. Executors and partners of project were Ivano-Frankivsk Regional State Administration, Tourist Association of the Ivano-Frankivsk Region, Carpathian National Nature Park, EcoLogic Association (the Maramures county, Romania).

An important aspect of the cross-border interaction, which is not important in terms of its organizational design, is a part of region in the functioning of the
European regions. For the Ivano-Frankivsk region this are Euroregions "Carpathians" and "Upper Prut".

The development of the cross-border innovation infrastructure is an important aspect of the organizational design of the cross-border cooperation. Thus, in 2008 the Ministry of Regional Development in cooperation with the National Academy of Sciences of Ukraine on execution of n. 6 of CMU prescript on September 10, 2008, No. 1214 p. developed the project of "National Strategy for creating and maintaining of cross-border clusters" as a tool for implementation of the state regional cross-border policy. This document for the Ivano-Frankivsk region offers two cross-border cluster initiatives: 1) forest transboundary cluster (as part of the Carpathian border regions of Ukraine and neighbouring countries); 2) cross-border tourism and recreation cluster (as in the Carpathian border part of Ukraine and neighbouring countries). However, none of the proposed cross-border clusters in the IvanoFrankivsk region have effect.

In addition, the Ivano-Frankivsk region is a member of the cross-border partnership of the Cross-Border Cooperation Programme of European Neighbourhood and Partnership Instrument (CCP ENPI) (CCP ENPI, 2013) on the territory of Poland, Ukraine and Belarus, which is actively forming today with the EU support. As part of this program two major programs boosting regional development are implemented: TAIEX (Technical Assistance and Information Exchange) and Twinning (the exchange of management experience at the regional level). This cross-border partnership declared goals such as increasing competitiveness of regions that are involved in this partnership, improving socio-economic level of their development, strengthening cooperation of the border communities.

The Ivano-Frankivsk region makes border region of the area about $50 \mathrm{~km}$ to the state border with Romania. In general, today 10 checkpoints (control points) exist on the Ukrainian-Romanian border. Five of them are in the Transcarpathian region, there are two in the Chernivtsi region and three in the Odesa region. At the same time in there are no checkpoints in the Transcarpathian region. However, during the period of 2009-2013 local authorities of the Ivano-Frankivsk region and authorities of the allied Romanian county (Județ) Maramures actively conducted and continued to work for creating an international checkpoint Shybene-Poienile de Sub Munte for motor road and pedestrian traffic, which will be located $10 \mathrm{~km}$ from suburb Shybene of village Yavirnyk of Zelene village council in the Verkhovyna district, near mountain Kopylash (Marmaros array in the Chyvchyny mountains) at an altitude about 1600 meters above sea level. Creating of this checkpoint will give the region a number of advantages:

- Transport advantages: increasing of passenger traffic volumes (including foreign tourists), moreover, not only in Romania but also in the Balkans countries that 
will be an additional source of revenue for local and state budgets. According to project estimates (Galicia NP in Ivano-Frankivsk, 2013) an average income will be about $115 \mathrm{mln}$. euro in the next 5 years after opening the crossing point; transport links to the southern districts of Ivano-Frankivsk region will be improved significantly, the construction of highway of 4 category is required after opening the checkpoint, which will connect the Transcarpathian region with the Romanian county Maramures (road held on from the Verkhovyna district to the border with Romania $(40 \mathrm{~km})$ through the villages Iltsi, Krasnyk, Topilche, Zelene and Yavirnyk);

- Investment advantages: at least three objects important for the economy of region and attractive for investment are allocated in the area of the possible checkpoint disposition, i.e. the Verkhovyna district (ski centers "Chornohora", "Krynta" and recreational complex "Hadzhyna"). Thus there are opened the opportunities for creation of new jobs, infrastructure development of the southern part of the region;

- Social benefits: creating at least 3,000 new jobs, on the one hand, and the development of tourism and recreational industry, on the other hand;

- Advantages tied with saving on transaction costs: according to project developers estimations (Radio România Internațional, 2013). In addition, it should be emphasized also on the synergy effect from deepening of international division of labor in adjacent regions in the perspective and mutual interlacing of national processes of production reproduction;

- Cross-border advantages: opening of the crossing will allow the wide implementation of the programs of cross-border cooperation with the Romanian side, and actually creation of checkpoint will be the first successful example of setting up of the cross-border cooperation. As a result the Verkhovyna district is able to transform from the "hard to reach corner" of the Ivano-Frankivsk region into the active cross-border cooperation.

The feature of the organizational infrastructure of border crossings is that in Ivano-Frankivsk act Polish visa center at the same time as the Romanian consulate or their representation is absent.

Based on all the above, we can formulate the following recommendations for enhancing of cross-border cooperation for Ivano-Frankivsk region: 1) Accelerating of the establishment of the Ukrainian-Romanian border crossing "Shybene-Poienile de Sub Munte"; 2) Activation of cooperation of the Transcarpathian region with other regions within Euroregion "Carpathians" and especially "Upper Prut"; 3) The creation of two cross-border clusters in the IvanoFrankivsk region (forestry and tourism); 4) Development of investment and innovative infrastructure in the region (based on such Transcarpathian innovative facilities as Galician innovation agency, Oil and Gas Science Park, etc.); 5) Construction of border infrastructure in the Verkhovyna district within opening of the new border crossing, development of its organizational infrastructure. Even from 2005 the representation of the Romanian Consulate in Chernivtsi was planned to open in Ivano-Frankivsk, but this initiative has not been implemented. In our view, this creates a serious barrier to cross-border cooperation with the Romanian side today; 6) Promoting of the consistent growth of trade turnover between the Ivano-Frankivsk region and neighbouring Romanian regions; 7) Establishment of special or free economic zone in the Verkhovyna district for attraction of foreign, primarily Romanian, investments.

Despite the wide range of outstanding common problems from problems of delimitation and infrastructural improvement of the Ukrainian-Moldovan state border to all-round issues of environmental safety, the development of the Ukrainian-Moldovan transborder region going reinforced rapidly. This is evidenced by the growth of the number of the European regions, active intergovernmental dialogue on trade and economic cooperation, intensification of cultural, scientific and educational cooperation.

The structure of the Ukrainian-Moldovan TBR includes the administrative-territorial units of the Republic of Moldova: 10 districts (Causeni, Soroca, Cahul, Stefan-Voda, Oknita, Donduseni, Briceni, Cimislia, Basarabeasca, Taraclia) and two autonomous entities - Transnistria and Gagauzia, and the Chernivtsi, Vinnytsia and Odesa regions from the Ukrainian side.

The legal bases for the development of the UkrainianMoldovan transborder region are as follows:

Interstate agreements:

- Treaty of Good Neighborhood, Friendship and Cooperation between Ukraine and the Republic of Moldova dated January 5, 1997.

Agreements about the cross-border cooperation between neighbouring countries:

- Joint Operational Programme of the European Neighborhood and Partnership Instrument (crossborder cooperation program) "Romania - Ukraine Republic of Moldova 2007 - 2013";

- On April 15, 2015, the selection of projects under the EU-funded program of support of territorial cooperation of the countries of eastern partnership "Ukraine-Moldova" started;

Agreements on cooperation between the border regions of Ukraine and the administrative-territorial units of the Republic of Moldova:

- On March 11, 1997, in Chisinau the "Agreement between the Government of Ukraine and the Government of the Republic of Moldova on cooperation between the border regions of Ukraine and the administrative-territorial units of the Republic of Moldova" was signed.

Agreement between Ukraine and the Republic of Moldova on Local Border Movement:

- "Agreement between the Government of Ukraine and the Government of the Republic of Moldova on 
entry points through the Ukrainian-Moldovan state border and simplified passage of citizens living in border areas", signed on March 11, 1997 and came into force on August 12, 1997. Amendments to the agreement were filled by the Protocol of the parties on May 29, 2006.

Other intergovernmental agreements and framework documents that deal with the cross-border cooperation issues:

- On July 4, 1997, in the city of Izmail, the "Protocol on trilateral cooperation between the governments of Ukraine, the Republic of Moldova and Romania" was signed by the President of Ukraine L. Kuchma, President of the Republic of Moldova P. Lučinski and the President of Romania E. Konstantinescu;

Protocol on the establishment of diplomatic relations between Ukraine and the Republic of Moldova dated March 10, 1992;

- Consular Convention between Ukraine and the Republic of Moldova dated November 11, 1996;

- Agreement between Ukraine and the Republic of Moldova on the state border dated April 6, 2000;

- The Memorandum of Understanding ( $\mathrm{MoU})$ between Ukraine, the Republic of Moldova and the European Union Border Assistance Mission to Moldova and Ukraine (EUBAM) was signed on October 7, 2005;

- On February 22, 2013, in Vinnytsia, an Agreement between Ukraine and the Republic of Moldova on the regime of the Ukrainian-Moldavian state border, cooperation and mutual assistance on border issues was signed.

National legislation on cross-border cooperation: - On June 24, 2004, the Law of Ukraine "On Transboundary Cooperation" was adopted;

- On April 29, 2002 the Cabinet of Ministers of Ukraine adopted Resolution No. 587 "On Certain Issues of Cross-Border Cooperation and Euroregions Development";

- Order of the Cabinet of Ministers of Ukraine No. 59-p "Some issues of development of cross-border cooperation within the Euroregion "Upper Prut" dated February 14, 2002;

- In the State Program for the Development of CrossBorder Cooperation during 2011-2015 (approved by the Resolution of the Cabinet of Ministers of Ukraine No. 1088 on December 1, 2010), paragraph 7 of the measures for ensuring the development of cross-border cooperation for 2011-2015 indicates the completion of the development of the joint Ukrainian-Moldovan urban development project of the region involved in the cross-border cooperation;

- Decree of the President of Ukraine No. 271/94 dated June 3, 1994 "On Measures for the Development of Economic Cooperation of the Regions of Ukraine with the Adjacent Regions of the Republic of Belarus and the Administrative-Territorial Units of the Republic of Moldova".
Agreements between local authorities:

Cooperation agreements between adjoining territories:

- The agreement on the formation of the "Upper Prut" Euroregion was signed on September 22, 2000 in Botosani, Romania. From the Republic of Moldova Edinet, Falesti, Glodeni, Ocnita, Riscani, Briceni districts and the municipality of Balti included to the Euroregion;

- On February 2, 2012 in Kyiv official representatives of the Vinnytsia region and six districts of the Republic of Moldova (Donduseni, Ocnia, Rezina, Soroca, Floresti and Soldanesti) signed the Treaty on the creation of the Euroregion "Dniester";

- Agreements on trade-economic, scientific-technical and cultural cooperation between the Vinnytsia Regional State Administration and the Soroca District (dated September 25, 1999) and the Transnistrian region of the Republic of Moldova;

- Since 2004 there has been the agreement between the Yampil District State Administration of the Vinnytsia region and the Soroca District Council of the Republic of Moldova on trade, economic and cultural cooperation; - In 2012, agreements were signed on cooperation between the village of Oclanda (the Soroca district, the Republic of Moldova) and the village Balanivka (the Bershad district, the Vinnytsia region), the village of Cainarii-Vechi (the Soroca district, the Republic of Moldova) and the village of Klembivka (the Yampil district, the Vinnytsia region).

Joint strategies for the development of the crossborder cooperation between neighbouring countries: Operational Program of the European Neighborhood and Partnership Instrument (Cross-Border Cooperation Program) Romania - Ukraine - Republic of Moldova 2007-2013; The Black Sea Cross-Border Cooperation Program 2007-2013, which includes the Republic of Moldova and the Odessa region of Ukraine.

Other normative-legal and framework documents between local authorities dealing with the cross-border cooperation were issued, such as:

In August 2014, in the framework of the International Investment Forum in Vinnytsia, a protocol of intentions was signed for the construction of a combined bridge crossing between Cosauti (Moldova) and Yampil (Ukraine).

Regional legislation on cross-border cooperation: - "The Program of European Integration Border Cooperation and Interregional Relations of the Odessa region for 2008";

- On April 26, 2012 the Program of European Integration, Interregional Relations and the Formation of a Positive Image of the Odessa region for 2012-2013 was adopted.

Prospects of the Ukrainian-Moldovan transborder region development must be viewed in several ways:

- Problems of arranging of the Ukrainian-Moldovan state border and border infrastructure development; 
- Prospects of the Ukrainian-Moldovan cooperation within the Euroregions "Upper Prut", "Dniester" and "Lower Danube";

- The problem of the Transnistrian conflict settlement and resolving of related with it socio-economic issues;

- Intensification of trade and economic cooperation and potential of the Ukrainian-Moldovan TBR, including within the regional association of countries of the Organization for Democracy andEconomic Development GUAM, which runs the spheres of economy, trade, energy and fights against international crime;

- The implementation of a number of important infrastructural projects in TBR (restoration of preserved construction of the railway Izmail-Reni even in 2008 (for unloading of so-called Bender railway junction and avoiding of multiple changing by Moldovan side of customs regulations for port Reni), the construction of the railway route Berezyne - Bassarabeasca, the construction of bridge over the Dniester estuary and bridge Yampil Cosauti (across the Dniester river), modernization and electrification of the rail track Bilhorod-Dnistrovskyi - Izmail, restoring with the best option water route through the Ukrainian part of the Danube delta, the search for alternatives to Moldovan GRES and power plant Vulcanesti (in Transnistria) for power supporting of some districts of the Odesa region of Ukraine);

- Solving of environmental problem issues in the transborder region (flood system for the Dniester and Danube rivers, hydrometeorological monitoring system for problem areas, ecological danger of the Moldovan refinery near the village Giurgiulesti, located on the border, about forty entities in the Ukrainian Danube, which can be a source of environmental threat, the threats to ecosystem of Danube Biosphere Resort from the side of erected deepwater navigable channel Danube the Black Sea by Ukraine in 2007).

Specifically first, most multidimensional issue characterized by a number of key features: 1) The current state of demarcation of the Ukrainian-Moldovan border, safety and accountability of which is the key to the successful flow of the European integration and Euro-Atlantic processes on both sides of it; 2) The role of the Transnistrian conflict in border issues of Ukraine and Moldova; 3) The effectiveness of the mission of the European Commission on the Transnistrian section of the state border between Ukraine and Moldova; 4) The value of demarcation of the Ukrainian-Moldovan border to the integration processes and the development of the cross-border cooperation in the region.

\section{Conclusions}

As the current practice shows, regional authorities of the Ivano-Frankivsk region focused in the field of international cooperation mostly on Polish vector. In our view, this regional policy is not quite correct, because this situation exacerbates regional disparities of socioeconomic development of the Ivano-Frankivsk region, particularly its northern and southern parts. Namely TBR activation with the Romanian side will create conditions for transformation of Verkhovyna districts and other southern districts in the Transcarpathian region in zone of accelerated economic development in perspective. This can be done through the development of transport, tourism and recreational, finance, logistics infrastructure, increasing of investment attractiveness of territory. And for achieving this purpose it is necessary to create the special economic zone (SEZ) or free economic zone (FEZ) for encouraging of the involvement of foreign, especially Romanian investors, in the southern districts of Ivano-Frankivsk region. The potential of the RomanianUkrainian interaction in the region is significant, but for now it is just the beginning of the realization.

Thus, the problems of border regions of Ukraine, Moldova and the EU are diverse and multifaceted, and their comprehensive solution requires the joint efforts of all participants in cross-border cooperation. At the same time the leading theme of this interaction must be European integration movement of Ukraine and Moldova.

\section{References:}

Hacman, S. (2004). Starea relațiilor interetnice în regiunea Cernăuți și perspectivele lor în contextul activității Euroregiunii "Prutul de Sus" [Status interethnic relations in Chernivtsi region and their prospects in the context of work Euroregion "Upper Prut"]. Relatii etnice pe teritoriul euroregiunii "Prutul de Sus" [Ethnic relations on the territory of the Euroregion "Upper Prut"]. Chernivtsi: Bukrek.

Havashi, O. (2013). Ukraiins'ko-slovats'ki vidnosyny protyahom ostann'oho chasu nabuly oznaky stratehichnykh [Ukrainian-Slovak relationship recently has become signs of strategic]. Zakarpattya Online Beta. Retrieved from: http://zakarpattya.net.ua/News/111860 (accessed 15 October 2019).

Kish, Y. V. (2004). Rehional'na polityka ES pislia ioho rozshyrennia: Analitychni otsinky Natsional'noho instytutu stratehichnykh doslidzhen' [The regional policy of the EU after its enlargement: Analytical evaluations of the National Institute of Strategic Studies]. Uzhgorod: Lear.

Kotsur, V. V. (2013). Etnopolitychnyi konflikt u Prydnistrov"ii u konteksti ukraiins'ko-moldovs'kykh mizhderzhavnykh vidnosyn [Ethnic and political conflict in Transnistria in the context of Ukrainian-Moldovan intergovernmental relations]. Kyiv: Kuras Institute of Political and Ethnic Studies of the NAS of Ukraine.

Kryvous, V. B. (2006). Zony vysokykh tekhnolohii v systemi innovatsiinoho rozvytku ES ta Ukraiiny [Zones of high technologies in the innovative development of the EU and Ukraine]. Ekonomika promyslovosti. Retrieved from: http://econindustry.org/archiv/mag/2006/vip_02_33/st_33_18.pdf (accessed 15 October 2019). 
Kulia, N. Transkordonnyi turystychnyi klaster abo maibutnie turyzmu Karpats'koho ievrorehionu [Cross-border tourism cluster or future tourism Carpathian Euroregion]. Uzhhorod National University. Retrieved from: http://zato.uz.ua/old/st29.html (accessed 15 October 2019).

Kyfiak, O. V. (2007). Rozvytok sfery rekreatsiinykh posluh rehionu v umovakh transkordonnoii spivrobitnytstva (na prykladi ievrorehionu "Verkhnii Prut") [The development of sphere of recreational services in the region in terms of cross-border cooperation (by example of Euroregion "Upper Prut")] (Ph.D. Thesis). Lviv: Institute of Regional Research of the NAS of Ukraine. Retrieved from: http://librar.org.ua/sections_load.php?s=business_economic science\&id=5799 (accessed 15 October 2019).

Milashovska, A. I. (2008). Rehional'na polityka sotsial'no-ekonomichnoho rozvytku prykordonnykh terytorii (na materialakh Karpats'koho rehionu) [Regional policy of socio-economic development of border areas (based on the Carpathian region)]. Uzhgorod: Karpaty.

Mitriaieva, S. I. (2005). Karpats'kyi ievrorehion - instrument ievrointehratsiinoii stratehiii Ukraiiny [Carpathian Euroregion - a tool of European integration of Ukraine]. Stratehichna panorama [Strategic Panorama], vol. 1.

Centre of Information for Neighborhood Programs "Romania-Ukraine" and CADSES (2016). Retrieved from: http://www.susidstvo.od.ua. (accessed 15 October 2019).

Program of Cross-Border Cooperation ENPI Hungary-Slovakia-Romania-Ukraine 2007-2013 (2013). Retrieved from: http://www.huskroua-cbc.net/ua/ (accessed 15 October 2019).

Shliakh na Balkany [Way to the Balkans] (2013). Halychyna [Galicia] (Internet newspaper). Retrieved from: http://www.galychyna.if.ua/publication/society/shljakh-na-balkani/print.html (accessed 15 October 2019).

Supreme Council of Ukraine (2008). Uhoda mizh Ukraiinoiu ta Slovats'koiu Respublikoiu pro mistsevyi prykordonnyi rukh [Agreement between Ukraine and the Slovak Republic on local border traffic]. Adopted on 2008, May 30. Retrieved from: http://zakon5.rada.gov.ua/laws/show/703_076 (accessed 15 October 2019).

Tunel' mizh Ukraiinoiu ta Slovachchynoiu buduvaly na ochakh meshkantsiv Uzhhoroda [Tunnel between Ukraine and Slovakia were built in view of residents of Uzhgorod] (2012). News Agency "UNIAN". Retrieved from: http://www.unian.ua/society/677528-tunel-mij-ukrajinoyu-ta-slovachchinoyu-buduvali-na-ochah-meshkantsivujgoroda.html (accessed 15 October 2019).

Ukraiins'ko-rumuns'ka zustrich u Iaremche [Ukrainian-Romanian meeting in Iaremche] (2013). Radio România Internațional. Retrieved from: http://www.rri.ro/uk_uk/Ukrayinsko_rumunska_zustrich_u_Yaremche-3652 (accessed 15 October 2019). 